\title{
Comparison Between Antioxidant Activities of Phenolic Extracts from Mexican Peanuts, Peanuts Skins, Nuts and Pistachios
}

\author{
Patricia Rosales-Martínez, ${ }^{1}$ Sofía Arellano-Cárdenas, ${ }^{1}$ Lidia Dorantes-Álvarez, ${ }^{2}$ Felipe García-Ochoa, ${ }^{2}$ and \\ Ma del Socorro López-Cortez*1 \\ ${ }^{1}$ Departamento de Biofísica, Escuela Nacional de Ciencias Biológicas, Instituto Politécnico Nacional. \\ 2 Departamento de Ingeniería Bioquímica, Escuela Nacional de Ciencias Biológicas, Instituto Politécnico Nacional. \\ Prol. de Carpio y Plan de Ayala, Col. Casco de Sto. Tomás, C.P. 11340, México D.F., socolc@prodigy.net.mx, \\ slopezc@encb.ipn.mx
}

Recived December 9 ${ }^{\text {th }}, 2012$; Accepted March 10 $0^{\text {th }}, 2014$

\begin{abstract}
Recently, several works have been done in order to study antioxidant compounds like resveratrol present in oilseeds since they are able to protect from cells damage related to heart disease and cancer. In the present research a chemical analysis and the identification of bioactive compounds of peanuts, nuts and pistachios varieties were carried out. The walnut variety showed the highest content of total phenolic compounds (1404 $\pm 23 \mathrm{mg} \mathrm{GAE} / 100 \mathrm{~g})$ and antioxidant capacity $(191 \pm 4.2 \mu \mathrm{mol} \mathrm{TE} / \mathrm{g})$. Phenolic compounds resveratrol, catechin, epicatechin and quercetin were identified in all samples.

Key words: Peanuts, antioxidants, nuts, pistachios, polyphenols, resveratrol.
\end{abstract}

\section{Introduction}

Consumption of oilseeds represent a healthy and inexpensive choice to prevent degenerative, cardiovascular and other chronic diseases, since they have an important nutritional value, contain proteins, unsaturated fatty acids [1,2], a variety of bioactive compounds with antioxidant properties like vitamin $\mathrm{E}$ and a complex mixture of phenolic compounds beneficial to human health [3-6]. Oilseeds such as nuts, pistachios and some legumes such like peanuts are an excellent source of polyphenolic antioxidants compounds, including resveratrol, a substance which has been found to have a protective function against cancer [7-9] as well as to decreases the risk of developing hypertension [10], cardiovascular disorders [11], degenerative nerve disease, Alzheimer's disease, and viral/fungal infections [12-14]. Furthermore, studies suggest that resveratrol reduces the risk of stroke by altering the molecular mechanisms in blood vessels (reducing susceptibility to vascular damage through decreased activity of angiotensin, a systemic hormone causing blood vessel constriction that would elevate blood pressure), and by increasing production of the vasodilator hormone, nitric oxide [15,16,7]. It also helps in the prevention of chronic degenerative diseases [17] and in preventing the growth of cancerous tumors [15].

Several studies have shown that nuts, pistachios and peanuts (also considered within the group of oilseeds due to their chemical composition), besides resveratrol other flavonoids as catechin, epicatechin and quercetin, which also have many beneficial effects on human health [8]. However, vegetables and seeds generally contain a mix of these phenolic compounds,
Resumen. En años recientes se han llevado a cabo estudios sobre el contenido de antioxidantes como el resveratrol presentes en oleaginosas ya que éstos protegen del daño celular relacionado con enfermedades cardiovasculares y cáncer. En la presente investigación se llevó a cabo el análisis químico e identificación de compuestos bioactivos en cacahuates, nueces y pistaches. La nuez de Castilla presentó el contenido más alto de compuestos fenólicos (1781 $\pm 381 \mathrm{mg}$ GAE/100 g) con capacidad antioxidante de $191 \pm 4.2 \mu \mathrm{mol} \mathrm{TE} / \mathrm{g}$. En todas las muestras analizadas se identificaron resveratrol, catequina, epicatequina y quercetina.

Palabras clave: Cacahuates, antioxidantes, nueces, pistaches, polifenoles, resveratrol

which interact with each other modifying the total antioxidant capacity. This could be due to the different mechanisms used by phenolic compounds to scavenge free radicals. Therefore, individual polyphenols should be identified in each sample [13]. On the other hand, the high polyphenols contents in peels, skin and seeds of nuts support the use of these agricultural by-products as sources of natural antioxidants. Considering the increased production and consumption of both natural and roasted oilseeds [18], and the existence of few reports comparing the contents of individual antioxidants in Mexican oilseeds, the aim of the present work was to determine the chemical composition and total phenols content, as well as to identify individual antioxidants such as resveratrol, quercetin, catechin and epicatechin from walnut, peanuts and pistachios of Mexican origin. The peanut skin was included in this study since it has been shown to be a potential source of natural antioxidants, even though is currently considered a by-product of the blanching process of peanuts and only used in the production of animal feed $[19,20]$.

The most commonly used techniques to identify individual polyphenols are: high-performance liquid chromatography (HPLC with UV-vis and fluorescence detection), HPLC coupled with mass spectrometry (HPLC-MS), capillary electrophoresis (CE), and gas chromatography, coupled with MS (GC-MS). However, some of them are mainly suitable for the analysis of the trans form, while some are suitable for the determination of both isomers [21] or when the objective is to identify most of the antioxidants present in the sample. In this study, high performance liquid chromatography (HPLC) with UV- vis detection) was used to identify only the major antioxidants of 
biological interest contained in the oilseeds (trans-resveratrol, catechin, epicatechin and quercetin). This method was selected due to its simplicity, speed and high-reproducibility.

\section{Experimental section}

Samples. Peanuts (Arachis hypogaea L.) of the Virginia, Spanish varieties (Mexican origin) and raw pistachio (Pistacia side L.) were acquired in the State of Morelos, Mexico (crop year 2009). Pecan nut Western variety (Carya illinoensis) and roasted pistachio Kerman variety (Iranian origin which was used for comparative purposes) were obtained from Leon, State of Guanajuato, Mexico. The walnut variety (Juglans regia) was obtained from the State of Puebla, México. Also, a sample of native walnut with physical characteristics similar to the pecan nut was obtained from San Luis Potosí (SLP), México (crop year 2009). Ripe peanut, walnut and pistachio seeds with good color were selected, discarding those that appeared damaged, rancid or unripe. In the case of peanuts, the skin was eliminated and analyzed separately.

Chemical composition. Proximate analysis. All determinations were performed in triplicate. All solvents and chemicals used were of analytical and HPLC grade (Fermont and Sigma).

The moisture content was determined in a Binder electric oven at $85{ }^{\circ} \mathrm{C}$ until a constant weight was reached [22]. The ether extract (\%) was determined by a modified Soxhlet method using a cellulose cartridge, a Soxhlet equipment and anhydrous petroleum ether [23]. The protein content was evaluated by digestion of the sample using the Kjeldahl's method (a digester and a micro stem destilation unit Scorpion Scientific), concentrated sulfuric acid catalyst $36 \% \mathrm{NaOH}$ solution, $4 \%$ boric acid and indicator mixture. For titration hydrochloric acid $0.1 \mathrm{M}$ was used [24]. The nitrogen content was estimated and converted to protein percentage by using the conversion factor $6.25[25,26]$. Nitrogen free extract was obtained by difference from the percentages of moisture, ash, crude fat and protein [27]. The crude fiber was determined by modified Kennedy method [28] where it was determined gravimetrically after chemical digestion and solubilization of other materials present. The fiber residue weight was then corrected for ash content after ignition. The mass loss corresponded to the crude fiber in the dried and defatted sample. The caloric content of the samples was determined by means of the factors proposed by Atwater, according to the following values: carbohydrates: $4 \mathrm{kcal} / \mathrm{g}$; protein: $4 \mathrm{kcal} / \mathrm{g}$; lipids $9 \mathrm{kcal} / \mathrm{g}$, [29].

Peanut roasting process. The roasting process of both varieties of peanuts was carried out in the laboratory in an electric Binder oven at $150{ }^{\circ} \mathrm{C}$ for $60 \mathrm{~min}$ [30]. $1 \mathrm{~kg}$ of peanuts was placed in an aluminum plate, subjected to heating and the peanuts were turned over every 10 minutes for 1 hour; then the samples were allowed to cool down for $30 \mathrm{~min}$ and stored in amber vials under refrigeration $\left(4^{\circ} \mathrm{C}\right)$ until use.

Methanol extraction. $0.5 \mathrm{~g}$ of each sample were placed in an amber vial and then $20 \mathrm{ml}$ of a $(70 / 30 \mathrm{v} / \mathrm{v})$ methanol/water were added (methanol HPLC grade, Sigma). Then the samples were stirred for 24 hours at room temperature $\left(25^{\circ} \mathrm{C}\right)$. Subsequently the extracts were filtered through Whatman filter paper no. 2 and stored in amber vials under refrigeration $\left(4{ }^{\circ} \mathrm{C}\right)$ until analysis [3].

Determination of phenolic compounds. The method reported by Tiemi et al. [3] was used to determine total phenols and antioxidant capacity. A $0.25 \mathrm{ml}$ aliquot of methanol extract and $2 \mathrm{ml}$ of distilled water were placed in an amber bottle and then $250 \mu \mathrm{l}$ of Folin Ciocalteu reagent (Sigma) were added. The mixture was allowed to stand for 3 minutes at $25{ }^{\circ} \mathrm{C}$ at room temperature, then $0.25 \mathrm{ml}$ of $7 \% \mathrm{Na}_{2} \mathrm{CO}_{3}$ solution were added and water was used to complete the volume to $3 \mathrm{ml}$. This mixture was incubed in a water bath at $37{ }^{\circ} \mathrm{C}$ for 30 minutes. After half an hour of reaction, the absorbance at $750 \mathrm{~nm}$ was measured in a UV-Vis spectrophotometer Thermo Scientific 10UV model and concentration was estimated using a calibration curve obtained with gallic acid within the range of 100-500 $\mathrm{ppm}$. The results were expressed as equivalent $\mathrm{mg}$ of gallic acid per $100 \mathrm{~g}$ of sample on dry basis (EAG/100 g db).

Determination of total antioxidant activity by DPPH. $100 \mathrm{ml}$ of a $0.1 \mathrm{mM}$ of DPPH (2,2-diphenyl-1-picryl hydrazil) Sigma solution, were prepared using methanol HPLC grade Sigma as solvent. Trolox (Sigma) standard solutions were prepared at concentrations of 200-1200 ppm in methanol. A blank was prepared (methanol-water 2:1) to adjust the instrument to zero. Samples of $100 \mu \mathrm{l}$ of methanol extract were added with $2.9 \mathrm{ml}$ of DPPH solution and allowed to react for $60 \mathrm{~min}$. The standards and samples absorbance was read at $515 \mathrm{~nm}$ on a UVvis spectrophotometer Thermo Scientific 10UV model. The extracts were tested by triplicate, using Trolox equivalent (TE) as reference standard and the results were expressed as $\mu \mathrm{mol}$ $\mathrm{TE} / \mathrm{g}$ of sample. The free radical scavenging (DPPH) percent was determined with absorbance values using the following equation: $\mathrm{CA}=[1-(\mathrm{A} 2-\mathrm{A} 3) / \mathrm{A} 1] * 100$, where: $\mathrm{CA}$ is the antioxidant capacity, $\mathrm{A} 1, \mathrm{~A} 2$ and $\mathrm{A} 3$ are the absorbance of the reference standard, sample, and sample blank respectively. The samples absorbance was interpolated in the calibration curve to get $\mu \mathrm{mol} \mathrm{TE} / \mathrm{g}$ sample of each oilseed extract [31].

\section{Determination of antioxidants by high performance liquid chromatography (HPLC)}

The modified method reported by Francisco and Resurrección was used [32]. Standard solutions were prepared in methanol at concentrations of $50,100,150,300$ and $600 \mathrm{ppm}$, and the absorption spectra were obtained at wavelengths of $306 \mathrm{~nm}$ for resveratrol, $280 \mathrm{~nm}$ for catechin and epicatechin and $370 \mathrm{~nm}$ for quercetin.

Samples extracts: $0.5 \mathrm{~g}$ of each sample were added to $20 \mathrm{ml}$ methanol and were mechanically stirred (LAB-LINE Instruments, Model No. 3508) for 24 hours at $25{ }^{\circ} \mathrm{C}$ [33]. Subsequently a vacuum evaporation was conducted on a rotary evaporator at $35{ }^{\circ} \mathrm{C}$ until dryness. Afterwards, samples were dissolved in $750 \mu \mathrm{l}$ of methanol HPLC grade and stored in amber vials under refrigeration at $4{ }^{\circ} \mathrm{C}$ until analysis. The extracts were dissolved in the mobile phase that consisted of $0.1 \%$ for- 
mic acid in double distilled water as solvent $\mathrm{A}$ and $0.1 \%$ formic acid in $100 \%$ acetonitrile as solvent B (HPLC grade reagents). Prior to HPLC analysis, the mobile phase was filtered through a Whatman Anopore inorganic membrane (Anotop 10 plus, 0.2 $\mu \mathrm{m})$. Subsequently A and B phases were shaken in a sonicator bath (Bransonic 1200) for 10 minutes to prevent formation of air bubbles. The column used in the analysis was Varian Omnispher 5, C18 column $(150 \times 4.6 \mathrm{~mm}), 5 \mu \mathrm{m}$ particle size, constant flow rate of $1 \mathrm{ml} / \mathrm{min}$; and the equipment a Varian 920 LC HPLC with diode array detector, automatic injection and injection volume of $40 \mu \mathrm{l}$. Chromatograms were obtained and each antioxidant was quantified by their corresponding calibration curve using the external standard method. An analysis of variance (ANOVA) was performed with a significance level of 0.05 , using the method of Duncan's multiple range to determine if there were significant differences between mean values for the different samples determined, getting standard deviations. The program used was the MINITAB version 16 .

\section{Results and Discussion}

Chemical analysis. Table 1 presents a comparison of the results of the proximate analysis for each sample, reporting the average value \pm standard deviation. Values obtained from crude fiber do not have a comparative analysis because literature only reports dietary fiber or fiber aggregate. Lipid values obtained from Mexican peanut crop samples (51.87\%) are similar to the values reported by Muñoz et al. [34] of Instituto Nacional de Ciencias Médicas y Nutrición Salvador Zubirán (INCMNSZ) $(51.45 \%)$ samples of Latin American origin. However, they are lower than those reported by Nus et al. [35], (71.97\%) which are of Spanish origin. Furthermore, it has been reported that Spanish crops are genetically modified or treated with fertilizer to increase oil production, which is commercially demanded [36]. This could be the reason for higher lipid content of the Spanish peanuts as compared to Latin American. Lipid values of the Mexican walnut crop (69.46 $\pm 0.21 \%)$ are similar to values reported by Muñoz et al. [33] and Nus et al. [35] $(65.21 \%)$, while the Western nut variety presented the highest value $(74.11 \pm 0.08 \%)$. The lipid values obtained from samples of raw pistachio from Mexico and roasted pistachio from Iran (58.14 \pm 0.8 and $51.81 \pm 0.15 \%$ respectively) are higher than the values reported (44.44\%) by Muñoz et al. [34]. The difference in lipid content between Mexican and Iranian pistachio can be attributed to the heat treatment, since it has been reported that roasting temperature has a greater effect on lipid oxidation than roasting time. It is therefore recommended to roast nuts at a moderate temperature $\left(130-150^{\circ} \mathrm{C}\right)$, for a longer period, rather than roasting at high heat for a shorter period of time [37].

The highest protein content was present in raw and roasted peanuts of the Virginia variety. The samples of pistachio showed the lowest value. Roasted peanuts Virginia and Spanish presented a value slightly smaller than the raw peanut samples, attributed to the roasting process that can produce structural changes of proteins as partial denaturation [38]. Hossame [39] reported that roasting caused native protein aggregation, which might simply result from the typical loss of tertiary structure followed by (reversible) unfolding, loss of secondary structure, cleavage of disulphide bonds, formation of new intra-/intermolecular interactions, rearrangements of disulphide bonds and the formation of aggregates. These modifications reflect a progressive transition to a disorganized structure with denaturation of proteins that adopt an unfolded conformation. The denatured molecules associate to form aggregates [40]. These results are in agreement with Beyer et al. (2001) [41], who observed significant protein denaturation in peanuts after 45 min roasting at $180{ }^{\circ} \mathrm{C}$.

The protein content of the two peanut varieties and Mexican walnut was higher than that reported by Nus et al. [35] and Muñoz et al. [34] being $9.7 \%$ and $17.3 \%$ respectively. The Western nut variety presented the lowest protein content. For the Mexican pistachio variety, the protein values obtained in the present study are similar to those reported by Nus et al. [35] and Muñoz et al. [34] (20.61\%). In Table 1, it is observed that at higher protein contents, the lipid content decreases. These differences are attributed, as mentioned above, to the origin of the seed [36].

The nitrogen-free extract content of all the studied samples (peanuts, nuts and pistachios) were lower than those reported

Table 1. Chemical composition of Mexican seeds per $100 \mathrm{~g}$ of dry matter.

\begin{tabular}{lccccccc}
\hline \multicolumn{1}{c}{ Variety } & Condition & Energy (kcal) & Humidity $(\%)$ & Lipids $(\mathrm{g})$ & Free extract N (g) & Protein $(\mathrm{g})$ & Crude fiber $(\mathrm{g})$ \\
\hline Peanut Virginia & raw & 612 & 2.91 & $47.14 \pm 0.15^{\mathrm{a}}$ & $17.93 \pm 0.26^{\mathrm{a}}$ & $29.03 \pm 0.17^{\mathrm{a}}$ & $3.47 \pm 0.07^{\mathrm{a}}$ \\
& roasted & 634 & 2.1 & $51.87 \pm 0.28^{\mathrm{b}}$ & $13.43 \pm 0.70^{\mathrm{b}}$ & $28.49 \pm 0.35^{\mathrm{b}}$ & $4.02 \pm 0.12^{\mathrm{b}}$ \\
Spanish & raw & 634 & 3.01 & $51.62 \pm 0.043^{\mathrm{a}}$ & $14.44 \pm 0.29^{\mathrm{a}}$ & $27.93 \pm 0.42^{\mathrm{a}}$ & $3.42 \pm 0.19^{\mathrm{a}}$ \\
& roasted & 640 & 2.38 & $52.49 \pm 0.12^{\mathrm{b}}$ & $17.65 \pm 0.27^{\mathrm{b}}$ & $24.43 \pm 0.26^{\mathrm{b}}$ & $3.23 \pm 0.02^{\mathrm{b}}$ \\
Walnut & & 714 & 1.7 & $69.46 \pm 0.21^{\mathrm{a}}$ & $5.2 \pm 0.37^{\mathrm{a}}$ & $17.06 \pm 0.15^{\mathrm{a}}$ & $6.35 \pm 0.04$ \\
Western nut & & 735 & 1.51 & $74.11 \pm 0.08^{\mathrm{b}}$ & $7.5 \pm 0.004^{\mathrm{b}}$ & $9.49 \pm 0.15^{\mathrm{b}}$ & $7.12 \pm 0.06$ \\
Mexican pistachio & Raw & 665 & 1.79 & $58.14 \pm 0.80^{\mathrm{a}}$ & $15.22 \pm 0.80^{\mathrm{a}}$ & $20.39 \pm 0.02^{\mathrm{a}}$ & $4.02 \pm 0.08^{\mathrm{a}}$ \\
Iranian pistachio & roasted & 635 & 2.82 & $51.81 \pm 0.15^{\mathrm{b}}$ & $21.54 \pm 0.16^{\mathrm{b}}$ & $20.64 \pm 0.016^{\mathrm{a}}$ & $3.34 \pm 0.14^{\mathrm{b}}$ \\
\hline
\end{tabular}

Note: Values are given as mean $\pm \mathrm{SD}$. Values not sharing a common superscript letter are significantly different at $\mathrm{p}<0.05$ (Duncan multiple range test). 
by Muñoz et al. (25.35\%), [34], and greater than that indicated by Nus et al. (4.43\%) [35]. The comparative analysis of fiber was not reported because in literature there is data of different types of fiber (crude fiber, total fiber) and dietary fiber, while the moisture content of all samples was less than 5\% and was similar to that reported by these authors. Significant differences $(p<0.05)$ values obtained in kilocalories and grams of protein from both peanut Virginia and Spanish varieties harvested in Mexico are attributed to the type of soil and climatic conditions in which they are harvested [42]. The energy value calculated in samples of Mexican harvested walnut and Western nut was higher than those of the peanuts and pistachios studied and it could be because they contain higher amounts of lipids. It also has higher values than those reported by Nus et al. [35] and Muñoz et al. [34]. In this study, a native nut from SLP (not shown) was analyzed, and the chemical composition of this variety has not been reported previously. However, it was considered for this analysis because of its very pleasant taste. In the proximate analysis of this sample, only moisture and lipids were determined, resulting in values of $1.90 \%$ and $35 \%$, respectively. The energy value found in the Mexican pistachio was higher than the one reported by Nus et al. [35] and Muñoz et al. [34], due to its higher lipid content.

It is statistically observed that the chemical composition of both varieties of nuts have significant differences $(p<0.05)$. There were also statistically significant differences $(p<0.05)$ in the chemical composition of raw Mexican and roasted Iranian pistachio, except for protein.

Higher contents of lipids and proteins in these seeds are related to higher nutritional quality, and most appreciated in the production of vegetable oils. The high quality of protein and lipids of nuts, peanut and pistachio is due to their content of polyunsaturated fatty acids such as omega 3 , Omega 6 , linoleic acid and linolenic acid, which are components of high nutritional value $[43,44]$. Data from the Mexican crop oilseeds are not yet reported in the INCMNSZ tables of nutritional composi- tion [34] since these data were collected from various sources (United States, Latin America, etc.).

\section{Determination of total phenolics (Folin-Ciocalteau)}

Peanut. Total phenol concentrations obtained for each variety of oilseeds are shown in Table 2 and are expressed as mg equivalents of gallic acid (mg EAG) by $100 \mathrm{~g}$ of sample on dry basis $(\mathrm{db})$. Average values are presented \pm standard deviation. The varieties of oilseed with the highest phenols content were the walnut and walnut SLP $(1404 \pm 23$ and $1363 \pm 11 \mathrm{mg} \mathrm{EAG/100}$ g sample respectively), followed by Western nut variety (1225 $\pm 11 \mathrm{mg}$ sample EAG/100 g db) and raw Mexican pistachio variety showed $566 \pm 13 \mathrm{mg}$ EAG/100 g, while the raw Spanish peanut variety had the lowest phenolic content $(301 \pm 11$ mg EAG/100 g sample). The amount of total phenols increased with the peanut roasting process in both varieties, this may be because temperature can lead to changes in the structure that result in a greater availability of antioxidant compounds [45].

It is well known that phenolic compounds are antioxidants [46]. Many antioxidant compounds in plants are mainly present as covalently bound forms with insoluble polymers. It is possible that heat disrupts the cell wall and releases antioxidant compounds, leading to an increase in antioxidant capacity [47, 48].

Furthermore, the increased content of phenolic compounds may also be due to the interference by other UV absorbing compounds such as amino acids and sugars present in extracts of samples, which were not corrected by the Folin-Ciocalteu assay. It has been shown that some methods of treatment such as boiling or heating increase the polyphenol content of food [49]. It was determined that there are significant differences ( $p$ $<0.05$ ) between the two varieties of raw and roasted peanuts. Nuts. The amount of total phenolics in Mexican walnut and SLP variety is similar to the value of the walnut $(1404 \pm 23$ and $1363 \pm 11 \mathrm{mg}$ EAG/100 g of sample respectively) reported by

Table 2a. Total phenolic content (mg EAG/100g dm) and Antioxidant capacity ( $\mu \mathrm{mol} \mathrm{TE} / \mathrm{g}$ $\mathrm{dm})$ of seeds.

\begin{tabular}{lccc}
\hline \multicolumn{1}{c}{ Variety } & Condition & $\begin{array}{c}\text { Total phenols } \\
(\mathrm{mg} \mathrm{EAG} / 100 \mathrm{~g} \mathrm{dm})\end{array}$ & $\begin{array}{c}\text { Antioxidant capacity } \\
(\mu \mathrm{mol} \mathrm{TE} / \mathrm{g} \mathrm{dm})\end{array}$ \\
\hline Virginia Peanut (seed) & Raw & $370 \pm 30^{\mathrm{a}}$ & $6 \pm 0.2^{\mathrm{a}}$ \\
& roasted & $457 \pm 39^{\mathrm{b}}$ & $8 \pm 0.1^{\mathrm{a}}$ \\
Spanish peanut (seeed) & Raw & $301 \pm 11^{\mathrm{c}}$ & $7 \pm 0.3^{\mathrm{b}}$ \\
& roasted & $441 \pm 12^{\mathrm{d}}$ & $8 \pm 0.2^{\mathrm{c}}$ \\
Walnut & - & $1404 \pm 23^{\mathrm{h}}$ & $191 \pm 4.2^{\mathrm{d}}$ \\
Western nut & - & $1225 \pm 11^{\mathrm{e}}$ & $172 \pm 3.0^{\mathrm{e}}$ \\
SLP nut & - & $1363 \pm 11^{\mathrm{h}}$ & $40 \pm 2.0^{\mathrm{f}}$ \\
Mexican pistachio & Raw & $566 \pm 13^{\mathrm{f}}$ & $34 \pm 2.6^{\mathrm{g}}$ \\
Iranian pistachio (Kerman) & roasted & $710 \pm 22^{\mathrm{g}}$ & $26 \pm 4.4^{\mathrm{h}}$ \\
\hline
\end{tabular}

Values are given as mean \pm SD. Values not sharing a common superscript letter are significantly different at $\mathrm{p}<0.05$ (Duncan multiple range test). 
Kornsteiner et al. [50], while Western nut is comparable to the value of the same variety (1284 $\mathrm{mg}$ EAG/100 g of sample) reported by these authors. Differences are attributed to the origin as well as the methods used for extraction. Ballard et al. (2009) [14] reported that both methanol and ethanol proved to be more efficient at extracting phenolic compounds than pure water.

Pistachios. Tiemi et al. [3] reported for roasted pistachio a value of $576 \pm 7 \mathrm{mg}$ EAG/100 g; for roasted Iranian pistachio the value was of $710 \pm 22 \mathrm{mg} \mathrm{EAG} / 100 \mathrm{~g}$, while Kornsteiner et al. [50] reported $867 \mathrm{mg} \mathrm{EAG/100} \mathrm{g,} \mathrm{without} \mathrm{specifying}$ whether this is roasted or raw, these are values higher than those obtained for the Mexican raw pistachio. The differences observed among the nuts, peanuts and pistachios can be attributed to the phenol extraction method, the origin, variety, soil type, harvest time, storage conditions, etc. [51].

Mexican pistachios have clearly not been roasted, since the shells do not open easily and therefore are not commercialized as such. So, in the present investigation, roasted pistachio from the Kerman variety (Iran) that is distributed in Mexico was used. However, it is reported that the difference between the raw and roasted pistachio can be explained by the roasting process performed at industrial level, where the nut is first placed in a $15 \%$ brine, dried at $70{ }^{\circ} \mathrm{C}$ for 3 minutes, and then roasted in an oven at $120^{\circ} \mathrm{C}$ for 10 minutes; this process causes structural changes in the compounds present in the seed [52].

Gentile et al. [53] conducted a comparative study between raw and roasted pistachio, reporting that the heat treatment (160 ${ }^{\circ} \mathrm{C}, 40 \mathrm{~min}$ ) decreases the phenolic content and antioxidant capacity, showing a total loss of vitamin $\mathrm{C}$ and proanthocyanidins, which contribute to the total antioxidant activity. Compounds such as isoflavones and polyphenols remain unchanged, a finding consistent with that reported by Stintzing et al. [54].

Fig. 1 shows a comparative analysis of the phenolic content of the samples against other nuts [3], This Fig. shows that Mexican harvested nuts have the highest values, followed by the Virginia peanut and Mexican raw pistachio analyzed in this study. The values are significantly higher than the other oilseeds shown in Fig. 1; even though the differences observed

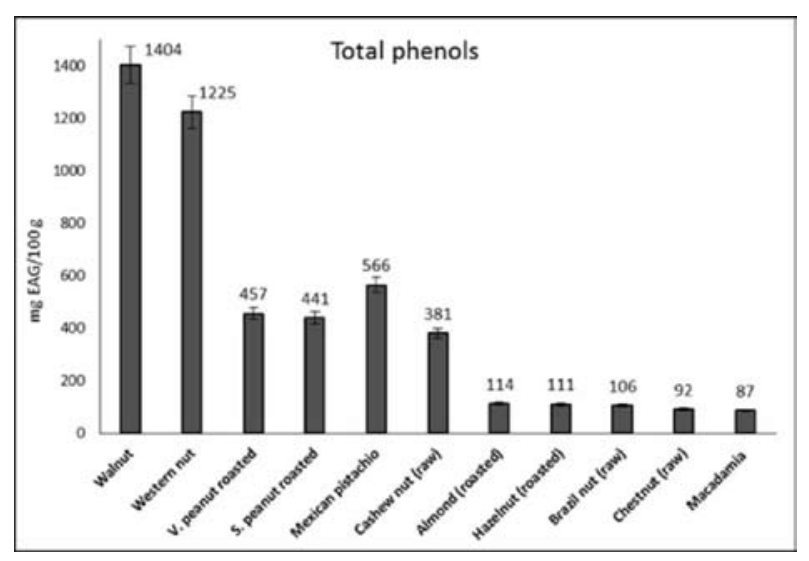

Fig. 1. Total phenolic content from different varieties of oilseeds, expressed as milligram of gallic acid equivalents per $100 \mathrm{~g}$ of dry matter (mg EAG/100g dm) (Tiemi et al. 2010). V.: Virginia; S.: Spansih. are due to both the origin and the extraction methods employed but still a large difference is observed among them.

The total phenolic content obtained for each variety of peanut skin is shown in Table $2 b$. Defatted samples were used because it has been reported that this condition favors the availability of phenolic compounds $[55,56]$. The largest amount of total phenols in roasted peanut skin was found in the defatted Virginia variety $(1779 \pm 4 \mathrm{mg}$ EAG/100 g) followed by the defatted Spanish variety with $1477 \pm 4 \mathrm{mg}$ EAG/100 g. This is justified because the heat applied during roasting favors the availability of phenols. Moreover, the defatting extraction method for the skin is performed for a period of 10-16 $\mathrm{h}$ at $40{ }^{\circ} \mathrm{C}$, process that may help the extraction of phenolic compounds [57]. It was also found that the content of phenolic compounds in the peanut skin was superior to that found in the seed, because the skin is the external part of the seed that protects from stress conditions and therefore most polyphenols are synthesized in this structure [58]. These results agree with Nepote et al. [56] who explained the differences considering origin, variety and ripening stage of the fruit.

Determination of the antioxidant capacity (DPPH method). The antioxidant capacity of the oilseeds is shown in Table 2. Average values are presented \pm standard deviation. Samples with higher antioxidant capacity were nuts in the following order: walnut $>$ Western $>$ SLP, while the raw peanut variety Virginia had the lowest value and pistachios an intermediate value between peanut and walnut. In the peanut, the highest antioxidant capacity was presented in the sample roasted Spanish variety, higher than that reported by Tiemi et al. [3]. Raw peanut antioxidant capacity was minor than the roasted samples. Tiemi et al. [3] reported that the antioxidant capacity depends on the type of phenolic compounds present in the sample. Furthermore, Lotis and Resurrección [33], refer that during heat treatments the Maillard reactions developed are responsible for the increase in total antioxidant capacity of foods. Maillard

Table 2b. Total phenolic content (mg EAG/100g bs) and Antioxidant capacity ( $\mu \mathrm{mol} \mathrm{TE} / \mathrm{g} \mathrm{dm})$ of peanut skin.

\begin{tabular}{lcc}
\hline \multicolumn{1}{c}{ Variety } & $\begin{array}{c}\text { Total phenols } \\
(\mathrm{mg} \mathrm{EAG} / \mathrm{g})\end{array}$ & $\begin{array}{c}\text { Antioxidant } \\
\text { Capacity } \\
(\mu \mathrm{mol} \mathrm{TE} / \mathrm{g})\end{array}$ \\
\hline $\begin{array}{l}\text { Raw peanut skin (Virginia) } \\
\text { Non-defatted }\end{array}$ & $1329 \pm 5^{\mathrm{a}}$ & $27.03 \pm 0.02^{\mathrm{a}}$ \\
$\begin{array}{l}\text { Defatted } \\
\text { roasted peanut skin (Virginia) }\end{array}$ & $1620 \pm 8^{\mathrm{b}}$ & $26.04 \pm 0.02^{\mathrm{a}}$ \\
Non-defatted & $1320 \pm 6^{\mathrm{c}}$ & $27.38 \pm 0.13^{\mathrm{b}}$ \\
$\begin{array}{l}\text { Defatted } \\
\text { Raw peanut skin (Spanish) }\end{array}$ & $1779 \pm 4^{\mathrm{d}}$ & $25.97 \pm 0.08^{\mathrm{c}}$ \\
Non-defatted & $1362 \pm 6^{\mathrm{e}}$ & $25.02 \pm 0.04^{\mathrm{d}}$ \\
Defatted & $1418 \pm 7^{\mathrm{f}}$ & $22.04 \pm 0.02^{\mathrm{e}}$ \\
roasted peanut skin (Spanish) & & \\
Non-defatted & $1408 \pm 13^{\mathrm{h}}$ & $27.28 \pm 0.02^{\mathrm{f}}$ \\
Defatted & $1477 \pm 4^{\mathrm{h}}$ & $21.10 \pm 0.06^{\mathrm{g}}$ \\
\hline Vales are given as
\end{tabular}

Values are given as mean \pm SD. Values not sharing a common superscript letter are significantly different at $p<0.05$ (Duncan multiple range test). 
reactions can produce several antioxidants with strong reducing power, such as amino acid reducers (Amadori compounds and Maillard -type polymers), their concentration may increase with an increase in exposure to heat treatment. Dewanto et al. [59] and Turkmen et al. [60] reported that heat treatments enhanced antioxidant capacity in pepper, green bean, broccoli, spinach, sweet corn and peanut (Arachis hypogaea).

The antioxidant capacity of both Western nut and walnut was higher than that reported by Tiemi et al. [3], while that of raw Mexican pistachio was higher when compared to roasted pistachio of the Iranian Kerman variety, and the value reported by Tiemi et al. [3], but lower than that reported by Bolling et al. [6]. These differences have generally been attributed to the origin of each oilseed variety, harvest time and storage, as well as the methods used for extraction and quantification of the antioxidant capacity of the analyzed samples.

A comparative analysis of the antioxidant capacity of other nuts consumed in Mexico is presented in Fig. 2, which shows that the antioxidant capacity of Mexican harvest nuts have higher values as compared to other nuts [3]. Similarly, the Virginia and Spanish variety peanuts and walnuts, Western and San Luis Potosi, showed higher values of antioxidant capacity.

The antioxidant capacity of raw skin and roasted peanuts Virginia variety was slightly higher in the defatted samples. The same occurred with the samples of the Spanish variety. The raw and roasted conditions also showed slight differences that are mainly attributed to differences in extraction methods. This comparative study of the skin of raw and roasted peanuts has not been reported previously. So far there were also no reports of comparative analysis between defatted and non-defatted samples. It is important to bear in mind that the peanut skin represents a potential source of natural antioxidants suitable for use as food additives, as reported by Larrauri et al. [61]. The antioxidant capacity of these samples depends on the mining methods employed, type of sample (skin or seed), origin, and storage time, among others.

Determination of antioxidants by HPLC. Fig. 3 shows the chromatogram obtained from the mixture of the four standards.

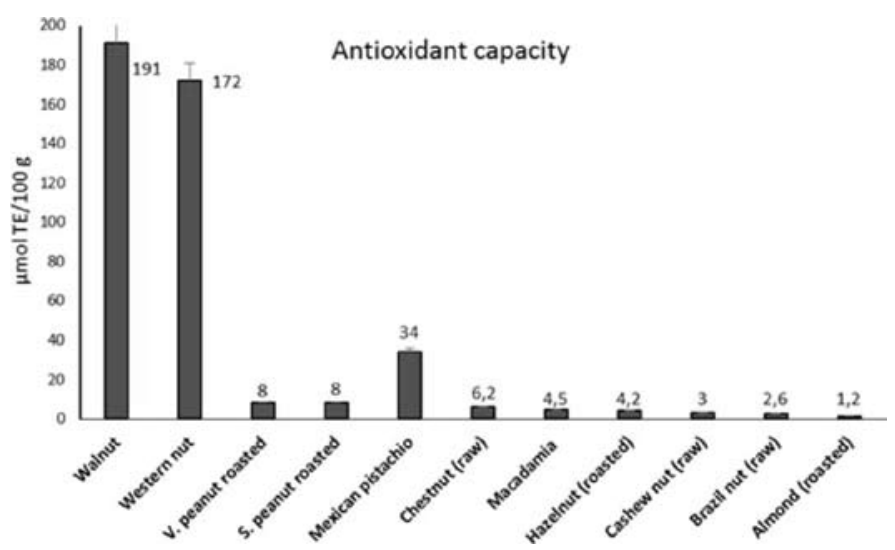

Fig. 2. Antioxidant capacity from different varieties of oilseeds, expressed as micromol of Trolox equivalents per $100 \mathrm{~g}$ of dry matter ( $\mu \mathrm{mol}$ TE/100g dm). V.: Virginia; S.: Spanish.

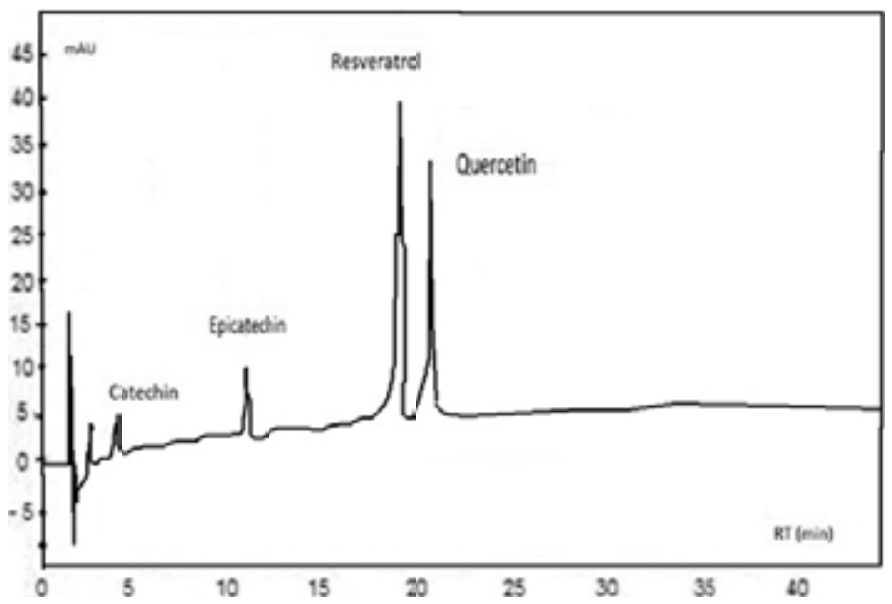

Fig. 3. Polyphenols standard Chromatogram, RT: Retention time (min), mAU: area units.

The retention times of each standard were: $19.47 \mathrm{~min}$ for resveratrol, $4.96 \mathrm{~min}$ catechin, $11.52 \mathrm{~min}$ epicatechin and 21.35 min for quercetin.

For comparative analysis, Fig. 4, 5, and 6 presented the overlap of the chromatograms obtained at wavelengths of each antioxidant.

These figures show the chromatograms obtained from a sample of each oilseed corresponding to Virginia peanuts, Mexican pistachio and Western nut respectively. The four polyphenols were identified at the corresponding retention times in all samples, but quercetin was not identified in the walnut sample (Table 3).

Antioxidants quantification in samples was performed using the standard curve of each compound and the results obtained are shown in Table 3. A comparative analysis of amounts

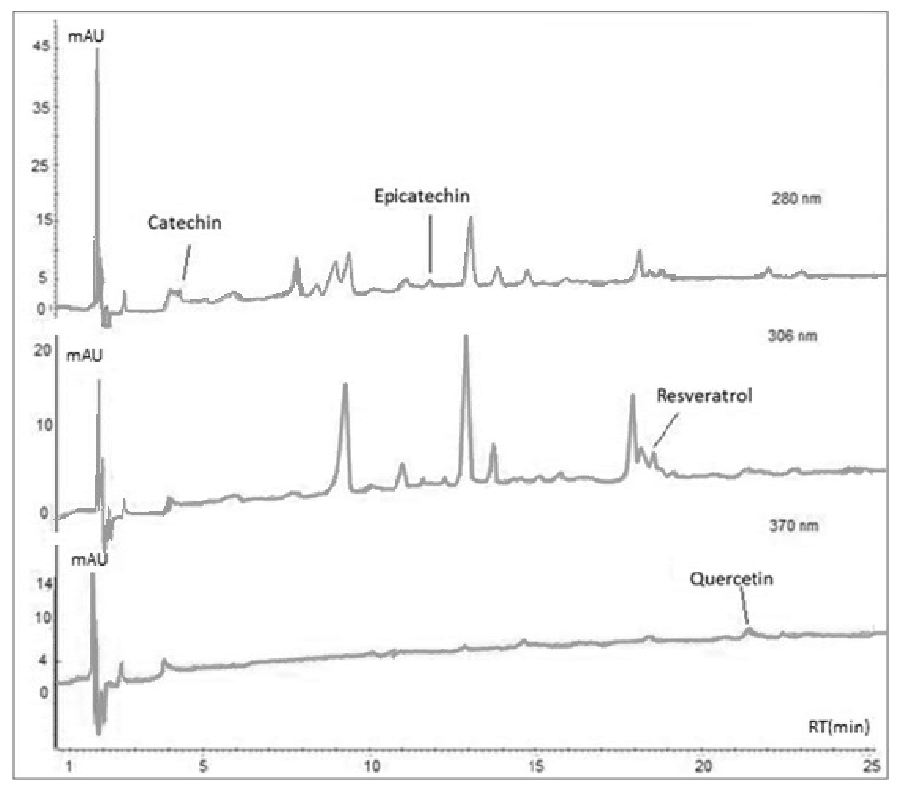

Fig. 4. Polyphenol chromatogram of toasted peanut Virginia variety. RT: Retention time (min), mAU: area units. 


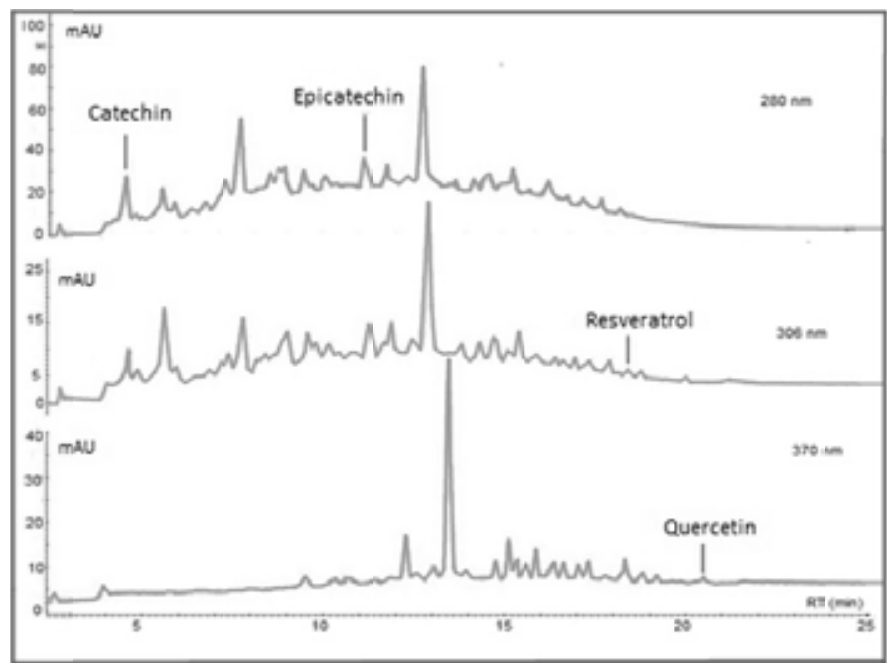

Fig. 5. Polyphenols chromatogram of Western nut variety. RT: Retention time (min), mAU: area units.

of these antioxidants with those reported by other authors is presented in Table 4. The value for resveratrol obtained in all samples was higher than those reported in literature, it maybe because other authors have used different extraction systems, solvent and mobile phases in the HPLC equipment and it should also be considered that samples are analyzed are from different origin, ripening stage, etc. so the comparative analysis is an approximate.

Win et al. [62] report quercetin in peanut and Ballisteri et al. [63] in pistachio (Table 4), and their values are lower than those found in the samples of the present work. The epicatechin for peanut samples has not been reported in the literature. The amounts reported in Table 3 were obtained by the method proposed by Francisco and Resurrección, [31] (modifying the mobile phase and the analysis conditions as mentioned in methodology), who report the sum of catechin and epicatechin (1956

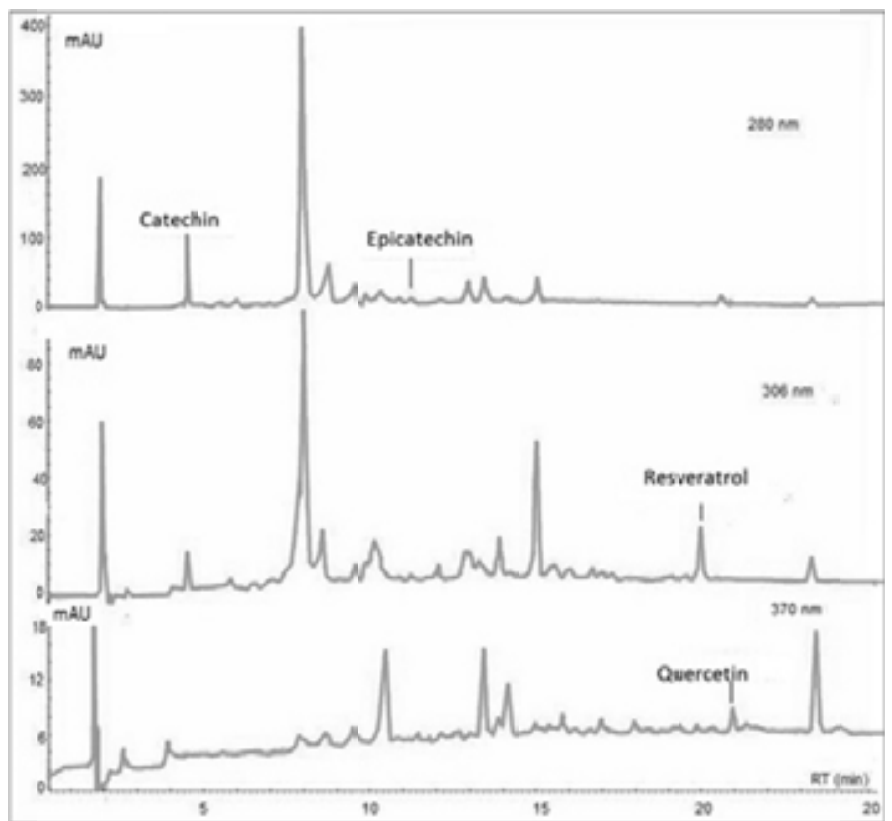

Fig. 6. Polyphenols chromatogram of raw pistachio Mexican variety. RT: Retention time (min), mAU: area units

$\mathrm{mg} / \mathrm{g}$ for raw peanut Virginia and $1962 \mathrm{mg} / \mathrm{g}$ for raw Spanish peanuts), values higher than the values obtained here (Table 3 ). In this paper, an approximate quantification of catechin and epicatechin is reported, due to the overlapping observed in these two antioxidants. Chukwumah et al. [49] reported very low values for catechin as compared to the peanut values obtained in the present study, while Yang et al. [64] reported a higher value $(189 \pm 13.1 \mathrm{mg} / \mathrm{g})$.

In the three walnut varieties analyzed, catechin values were lower than those reported by Yang et al. [64] and Bolling et al. [6] which could be due to the extraction conditions and analysis, as well as their origins. Finally, values of catechin and

Table 3. HPLC quantitative analysis of polyphenols present in Mexican oilseeds $(\mu \mathrm{g} / \mathrm{g}$ sample).

\begin{tabular}{lccccc}
\hline \multicolumn{1}{c}{ Sample } & Condition & $\begin{array}{c}\text { Resveratrol } \\
(306 \mathrm{~nm})\end{array}$ & $\begin{array}{c}\text { Catechin } \\
(280 \mathrm{~nm})\end{array}$ & $\begin{array}{c}\text { Epicatechin } \\
(280 \mathrm{~nm})\end{array}$ & $\begin{array}{c}\text { Quercetin } \\
(370 \mathrm{~nm})\end{array}$ \\
\hline Peanut Virginia & raw & 5.84 & 114.35 & 262.23 & 49.42 \\
& roasted & 8.24 & 122.14 & 238.04 & 49.62 \\
Peanut Spanish & raw & 8.99 & 116.30 & 222.00 & 49.42 \\
& roasted & 5.15 & 115.64 & 189.66 & 49.75 \\
Skin C. Virginia & raw & 7.20 & 113.70 & $\mathrm{NC}$ & 48.43 \\
& roasted & 7.90 & 113.05 & $\mathrm{NC}$ & 49.42 \\
Skin C. Español & raw & 5.84 & 114.35 & $\mathrm{NC}$ & 52.63 \\
& roasted & 5.15 & 114.99 & $\mathrm{NC}$ & 51.82 \\
Walnut & & 5.84 & 129.94 & 2237.32 & - \\
SLP nut & & 5.15 & 121.50 & 238.04 & 47.39 \\
Western nut & & 5.15 & 133.19 & 278.00 & 49.50 \\
Mexican pistachio & raw & 14.73 & 155.29 & 213.85 & 49.42 \\
Iranian pistachio & roasted & 7.20 & 160.49 & 133.22 & 50.22 \\
\hline
\end{tabular}


Table 4. Comparative table of bioactive content in oilseeds by HPLC ( $\mu \mathrm{g} / \mathrm{g}$ sample).

\begin{tabular}{|c|c|c|c|c|}
\hline Author & Sample & Resveratrol & Catechin & Quercetin \\
\hline \multicolumn{5}{|c|}{ Peanut } \\
\hline Sobolev and Cole, (1999) & & $0.055 \pm 0.023$ & NR & NR \\
\hline Sanders et al. (2000) & & 1.792 & & \\
\hline Lee et al. (2004) & $\begin{array}{l}\text { raw Virginia } \\
\text { raw Español } \\
\text { comercial peanut }\end{array}$ & $\begin{array}{l}0.25 \\
0.30 \\
0.13\end{array}$ & NR & NR \\
\hline Tokusoglu et al (2005) & & $0.03-1.92$ & & \\
\hline Chukwumah et al. (2007) & $\begin{array}{l}\text { raw } \\
\text { raw with skin } \\
\text { roasted }\end{array}$ & NR & $\begin{array}{l}0.01 \pm 0.00 \\
0.05 \pm 0.00 \\
0.01 \pm 0.00\end{array}$ & NR \\
\hline Yang et al. (2009) (mg/100 g) & & NR & $189.8 \pm 13.1$ & NR \\
\hline Bolling et al. (2010) & $(\mathrm{mg} / 100 \mathrm{~g})$ & NR & 0.66 & NR \\
\hline Win et al. (2011) & seed & $0.10 \pm 0.04$ & & $12.40 \pm 1.2$ \\
\hline \multicolumn{5}{|c|}{ Nut } \\
\hline Yang et al. (2009) & $\begin{array}{c}\text { Pecan } \\
\text { nut* }\end{array}$ & NR & $\begin{array}{l}7047 \pm 29.5 \\
7448 \pm 93.3\end{array}$ & \\
\hline John and Shahidi, (2010) & & & 2.61 & NR \\
\hline Bolling et al. (2010) & Pecan nut (Walnut)* & NR & 1599685 & NR \\
\hline \multicolumn{5}{|c|}{ Pistachio } \\
\hline Tokusoglu et al. (2005) & & $0.09-1.67$ & NR & NR \\
\hline Grippi et al. 2008 & & $\begin{array}{c}\text { Trans } 0.07-0.18 \\
\text { piceid } 6.20-8.15 \\
\text { total } 6.38-8.27\end{array}$ & NR & NR \\
\hline Ballistreri et al. (2009) & $\begin{array}{l}\text { pistachio not mature } \\
\text { pistachio mature }\end{array}$ & $\begin{array}{l}1.7 \pm 0.1 \\
1.2 \pm 0.1\end{array}$ & NR & $\begin{array}{l}2.3 \pm 0.1 \\
1.7 \pm 0.3\end{array}$ \\
\hline Tomaino et al. (2010) & Pistachio & & $2.41 \pm 0.18$ & NR \\
\hline
\end{tabular}

$\mathrm{NR}=$ No reported. $*$ Common nut (Yang et al. 2009).

epicatechin for pistachio samples were only found at Tomaino et al. [65], who reported a value of $2.41 \pm 0.18 \mathrm{mg} / \mathrm{g}$, which were lower than the obtained in this work.

\section{Conclusions}

In this study it was possible to identify four of a series of polyphenols present in these samples, so it is important to identify the rest of these compounds in later studies. The comparative analysis of the Mexican oilseeds established that peanuts, nuts and pistachios have good levels of bioactive compounds, and peanut skin could be used as an additive in the preparation of functional foods. The differences of results of proximate analysis, total phenolic content, antioxidant capacity and the amount of individual antioxidants present in the three samples of nuts, pistachios and peanuts studied, were attributed to the variety, the place of origin, harvesting and storage time and generally to the extraction methods used and quantification of phenols.

The analyzed walnut samples in the present study can be considered of high quality due to its large content of antioxidants. These information has not been reported before, because the Official Mexican Standard [66] classifies walnuts considering only the color and percentage of edible portion, type and size (grade I and II). The studied peanuts had good levels of lipids, proteins and antioxidant compounds. The information showed in this work is relevant when considering that in recent years Mexico has reached second place worldwide in production of walnut and peanut. Even so, pistachio is only intended for use as fodder, despite its content of bioactive compounds as determined in this research.

\section{Acknowledgements}

The authors wish to thank the Secretaría de Investigación y Posgrado of Instituto Politécnico Nacional (SIP-IPN) for the financial support to this work.

\section{References}

1. Suwatchai, M.; Swatsitang, P.; Jogloy, S. Sci. J. 2008, 36, 6474. 
2. Schmidt, Š.; Pokorný, J. Czech. J. Food Sci. 2005, 23, 93-102.

3. Tiemi, L.; Lajolo, F.; Genovese, M. Ciênc e Tecnol Aliment. 2010, 30 (1), 254-259.

4. Chen, R.; Wu, P.; Chiou, Y. J. Agr. Food Chem. 2002, 50(6), $1665-1667$

5. Lattanzio, V. J. Appl. Bot. 2003, 77(56), 128-146.

6. Bolling, B.W.; McKay, D.L.; Blumberg, J.B. Asia Pac. J. Clin. Nutr. 2010, 19 (1), 117-123.

7. Dudley, J.; Das, S.; Mukherjee, S.; Das, D. J. Nutr. Biochem. 2008, 20(6), 443-452.

8. Kris-Etherton, P.M.; Hecker, K.D.; Bonanome, A.; Coval, S.M.; Binkoski, A.E.; Hilpert, K.F.; Griel, A.E.; Etherton, T.D. Am. J. Med. Sci. 2002, 113, 71S88S.

9. Martínez, J.; Evangelista, S.; Martínez, A. HYPATIA. 2007, 22 (6).

10. Djousse, L.; Rudich, T.; Gaziano, J.M. Clin. Nutr. 2009, 28, 1014.

11. Kris-Etherton, P.; Hu, F.; Ros, E.; Sabate, J. J. Nutr. 2008, 138 (9S-I), 1746S-1751S.

12. Tokusoglu, O.; Kemal, M.; Yemis, F. J. Agr. Food Chem. 2005, 53(12), 5003-5009.

13. Iacopini, P.; Baldi, M.; Storchi, P.; Sebastiani, L. J. Food Comp. Anal. 2008, 21, 589-598.

14. Ballard, T.S.; Mallikarjunan, P.; Zhou, K.; O'Keefe, S.F. J. Agr. Food Chem. 2009, 57(8), 3064-72.

15. King, R.; Bomser, J.; Min, D. Inst. Food Tech. 2006, 5, 65-70.

16. Udenigwe, C.C.; Ramprasath, V.R.; Aluko, R.E.; Jones, P.J.H. Nutr. Rev. 2008, 66(8), 445-454.

17. Frémont, L. Rev. Life Sci. 2000, 66(8), 663-673.

18. Secretaría de Agricultura, Ganadería, Desarrollo Rural, Pesca y Alimentación (SAGARPA), Foro de Perspectivas Económicas del Sector Agroalimentario. Financiera Rural. 2011, 1-10.

19. Hoang, V.H.; Apoštolová, P.; Dostálová, J.; Pudil, F.; Pokorný, J. Czech. J. Food Sci. 2008, 26, 447-457.

20. Yu, J.; Ahmedna, M.; Goktepe, I. Food Chem. 2005, 90, 199206.

21. Lee, S.; Kim, M.; Chun, J.; Cheong, Y.; Lee, J. Food Res. Int. 2004, 37: 247-51.

22. Association of Official Analytical Chemists. Official Methods of Analysis of AOAC (Method $N^{\circ}$ 925.09) (Method $N^{\circ}$ 993.21). 16th ed. USA, Washington, 1996.

23. NORMA MEXICANA. NMX-F-089-S-1978. Determinación de extracto etéreo (método Soxhlet) en alimentos.

24. NORMA MEXICANA. NMX-F-068-S-1980. Alimentos: Determinación de proteínas.

25. Nielsen, S. Food Analysis. Ed. Aspen Publisher, EU. 1998

26. Badui, S. Food Chemistry. Ed. Pearson Educatión, México. 2009.

27. González, M.; Mendoza, F.; Mora, J.; Mendoza, M.; Márquez, J.; Bravo, M. Rev. Fac. Farmacia. 2005, 47(1), 25-29.

28. Association of Official Analytical Chemists. Official Methods of Analysis of AOAC (Method $\mathrm{N}^{\circ}$ 962.09). 16th ed. USA, Washington, 1997.

29. Casanueva, E.; Kaufer, M.; Pérez, A.; Arroyo, P. Nutriología Médica. Ed. Medica Panamericana, México, 2006.

30. Food and Agriculture Organization (FAO). Manual de Procesos Agroindustriales. Proyecto de Capacitación para el Fomento de la Agroindustria Rural. USA. 2006.

31. Pinheiro, A.; Monalise, A.; Fett, R.; Mara, J. Rev. GyA. 2009, 60 (5), 458-467.

32. Francisco, M.L.; Resurrección, A.V. Food Chem. 2009, 117(2), 356-363.

33. Lotis, L.; Resurrección, A. J. Food Comp. Anal. 2009, 22, 1624.

34. Muñoz, M.; Ledesma, A.; Chávez, A.; Pérez, F.; Mendoza, E.; Calvo, C. Instituto Nacional de Ciencias Médicas y Nutrición Salvador Zubirán (INCMNSZ). Ed. McGraw Hill, México, 2009.
35. Nus, M.; Ruperto, M.; Sánchez, F. ALAN. 2004, 54 (2), 137-148.

36. Jonnala, R.; Dunford, N.; Chenault, K. J. Food Sci. 2005, 70(4), 254-256.

37. Yaacoub, R.; Saliba, R.; Nsouli, B.; Khalaf, G.; Birlouez-Aragon, I. J. Agric. Food Chem. 2008, 56 (16): 7082-7090.

38. Yu, J.; Ahmedna, M.; Goktepe, I. Food Chem. 2007, 103, 121-129.

39. Hossam, E. S. El-Beltagi. Int. J. Food Sci. Nutr., 2011, 62(5): 453-456

40. Luis, A.S.; Nelson, H.P.; Jaime, A.F. J. Food Sci. 2005, 70: 294300.

41. Beyer, K.; Morrow, E.; Li, X.M.; Bardina, L.; Bannon, G.A.; Burks, A.W.; Sampson, H.A. J Allergy Clin. Immunol. 2001, 107(6):1077-1081.

42. Secretaría de Agricultura, Ganadería, Desarrollo Rural, Pesca y Alimentación (SAGARPA), Centro de Investigación Regional del Centro Campo Experimental Zacatepec, 2002, 18: 1-41.

43. Yoshida, H.; Hirakawa, Y.; Tomiyama, Y.; Nagamizu, T.; Mizushina, Y. J. Food Comp. Anal. 2005, 18, 3-14.

44. Luna, J.; Guerrero, J. Selected Topics in Food Engineering. UDLAP. 2010, 4(1), 37-48.

45. Talcott, S.; Duncan, C.; Del Pozo, D.; Gorbet, D. Food Chem. 2005, 89, 77-84.

46. Cao, G.; Sofic, E.; Prior, R.L. J. Agr. Food Chem 1996, 44, 34263431.

47. Choi, Y.; Lee, S.M.; Chun, J.; Lee, H.B. J. Food Chem. 2006, 99 , 381-387.

48. Chumyama, A.; Whangchaia, K.; Jungklanga, J.; Faiyuec, B.; Saengnil, K. J. Sci Soc Thailand. 2013, 39: 246-251.

49. Chukwumah, Y.; Walker, L.L.; Vogler, B.; Verghese, M. J. Agr. Food Chem. 2007, 55(22), 9266-9273.

50. Kornsteiner, M.; Heinz, K.; Elmadfa, I. Food Chem. 2006, 98, 381-387.

51. Saitta, M.; Giuffrida, D.; Loredana, G.; Dugo, G. Food Chem. 2009, 117, 451-455.

52. Lemus, G.; Negrón, C. Ministerio de Agricultura. INIA- La Platina. Chile. 2004.

53. Gentile, C.; Tesoriere, L.; Butera, D.; Fazzari, M.; Monastero, M.; Allegra, M.; Livrea, M.A. J. Agr. Food Chem. 2007, 55, 643648.

54. Stintzing, F.C.; Hoffmann, M.; Carle, R. Mol. Nutr. \& Food Res. 2006, 50, 373-377.

55. Francisco, M.L.; Resurrección, A.V. Food Sci Tech. 2012, 47, 189-198.

56. Nepote, V.; Grosso, N.; Guzmán, C. Rev. GyA. 2002, 53(4), $391-$ 395.

57. Chukwumah, Y.; Walker, L.L.; Verghese, M.; Bokanga, M.; Ogutu, S.; Alphonse, K. J. Agr. Food Chem. 2007, 55(22), 285-290.

58. Francisco, M.L.; Resurrección, A.V. J. Food Comp Anal. 2009b, 22(1), 16-24.

59. Dewanto, V.; Wu, X.; Liu, R.H. J. Agr Food Chem. 2002, 50, 4959-4964.

60. Turkmen, N.; Sari, F.; Velioglu, Y.S. Food Chem. 2005, 93, 713718 .

61. Larrauri, M.; Zunino, P.; Terzariol, L.; Mestrallet, M.; Zygadlo, J.; Grosso, N.; Nepote V. INTA. 2011, 30, 79-81.

62. Win, M.; Abdul, A.; Baharin, B.; Anwar, F.; Sabu, M.; Pak-Dek, M. Pak J. Bot. 2011, 43(3): 1635-1642.

63. Ballistreri, G.; Arena, E.; Fallico, B. Rev Mol. 2009, 14, 43584369.

64. Yang, J.; Hai, R.; Halim, L. Food Sci Tech. 2009, 42, 1-8.

65. Tomaino, A.; Martorana, M.; Arcoraci, T.; Monteleone, D.; Giovinazzo, C.; Saija, A. Biochimie. 2010, 92, 1115-1122.

66. NORMA MEXICANA NMX-FF-084-SCFI-2009. Productos alimenticios no industrializados para consumo humano. Especificaciones y métodos de prueba.

67. Grippi, F.; Crosta, L.; Aiello, G.; Tolomeo, M.; Oliveri, F.; Gebbia, N.; Curione, A. Food Chemistry. 2008, 107: 483-488. 